\title{
Whose Knowledge? Epistemological \\ Collisions in Solomon Islands \\ Community Development
}

\section{David Welchman Gegeo and Karen Ann Watson-Gegeo}

Unless the South learns to harness the forces of modern science and technology, it has no chance of fulfilling its developmental aspirations or its yearning for an effective voice in the management of global interdependence. All its societies must therefore mount a determined effort to absorb, adapt, and assimilate new technological advances as part of their development strategies.

Julius Nyerere and others, The Challenge to the South

Traditional knowledge has frequently been over-looked in the search by outside professionals to find solutions to the development problems of the poor. ... However, increased use of traditionalknowledge maymake development programs more appropriate to local conditions, provide innovative solutions to certain problems, contribute to a sense of self-worth and collective self-esteem among local people, and enhance popular participation and empowerment. [Therefore] development programs should start with the premise that poor people ... are knowledgeable and skillful managers of their own environment.

John BRohman, Popular Development

$\mathrm{T}_{\mathrm{s}}$ he era of decolonization in Pacific Island nations began in the I960s as it did elsewhere in the Third World. ${ }^{1}$ More recently, the island Pacific seems to have entered a period of internal decolonization in the form of ethnic conflicts similar to those going on in Africa, Latin America, Asia, and Central Europe. For example, Fiji experienced its first ethnically based

The Contemporary Pacific, Volume I4, Number 2, Fall 2002, 377-409

(C) 2002 by University of Hawai'i Press 
political coup in 1987 (Lal 1988, I992; Lal and Nelson 1995), and its third in 2000 (Lal 2002). Beginning in I998, a conflict in Solomon Islands between indigenous peoples of Guadalcanal and immigrants from Malaita island has brought the country's economy to a virtual standstill, culminating in a paramilitary coup on 5 June 2000 and the establishment of an uneasy peace several months later. The roots of the ethnic conflict in the Solomons lie deep in its colonial history, but unequal distribution of resources has been an important factor. The major players on the Guadalcanal side of the ethnic conflict offered the same reasons for their actions that have been heard in other ethnic conflicts in the Pacific islands: people not receiving full benefits from development of their resources, their land being settled illegally by migrant groups who lack respect for local cultures, lopsided political representation in government, and so on (Kabutaulaka 1999; Kabutaulaka and others I999; Mamaloni and others I999; Solomon Islands Government 1999).

While these complaints are valid, the underlying causes have persisted in the Solomons because the structure and conceptualization of "development" has never really moved beyond classic modernization theory, emphasizing large-scale, top-down, center-periphery economic enterprises such as plantations, mining, logging, and export fisheries. If anything, the contemporary emphasis on globalization, global capitalism, economic restructuring, and free trade has intensified pressure on fragile economies like that of Solomon Islands to focus on large-scale, centralized, export industries. "Development" in the Solomons continues to depend on overseas aid and focus almost exclusively on economics and urban areas. It continues to ignore political, educational, and humanistic aspects, rural needs, and the importance of traditional cultures and their significance to national development (Roughan 1986, 1997; Gegeo 1994). Even nongovernmental organizations with messages of concern for cultural aspects of development have typically perpetuated the modernization paradigm and often undermined rather than supported indigenous countervoices (see Gegeo and Watson-Gegeo I999).

Eighty-five percent of Solomon Islanders live in rural areas, supporting themselves primarily by subsistence agriculture (Roughan I99I). Yet the national government, like the colonial government before it, has paid only scanty, sporadic attention to rural development. Because the national government is committed to a "ripple" effect in development (the idea that development at the center will ripple out to the periphery), it concentrates its efforts at the national level (Solomon Islands Government 1985). The 
government position has been that if national development succeeds, then everybody succeeds. Government officials distrust local villagers' ability to make "good use" of government investments in development, such as seed grants (Solomon Islands Government 1989). They tend to attribute small project failures to villager ignorance, lack of managerial skills, fatalistic attitudes, kin connections, and so on-echoing the arguments of classic modernization theorists (Lerner 1964; Apter 1987). But in reality, much of the failure of rural development in the Solomons is due to the persistent modernization paradigm under which development efforts are still governed (Gegeo 1994, I998). In this respect, Solomon Islands is still at least thirty years behind development theory and the more progressive practices in some other nations.

Despite the movement toward a more people-centered, bottom-up philosophy in development education and practice, in this article we show how modernization, globalization, and older Anglo-European notions of community development continue to fail rural development in the Solomons, by analyzing a specific rural development project aimed at assisting youth in Kwara'ae, Malaita (map I). The project functioned successfully for a decade until it was taken over by a retired government official. Because of his education, training, and experience working with outside development agencies, this retired government official imposed the government's modernization framework on the project, including the valuing of Anglo-European knowledge over indigenous knowledge, and the centralization of leadership and knowledge in one person. Both are contrary to indigenous ways of operating in which the knowledge behind a project is decentralized, along with leadership: that is, no single person is looked to as the expert on all aspects of the project because everyone contributes his or her expertise; and knowledge is regarded not as a static body of information, but as always undergoing (re)construction to make it relevant to changing conditions.

\section{The Argument for Indigenous Knowledge And INDIGENOUS EPISTEMOLOGY}

Among the differing perspectives argued in "alternative" and "sustainable development" (Friedmann I992; Taylor andMackenzie I992; Burkey I993; Singh and Titi 1995; Brohman 1996; Pieterse 1998), the past decade has seen a growing emphasis on the significance of local or indigenous knowledge in social change and development (Connerton I989; Cernea I99I; 


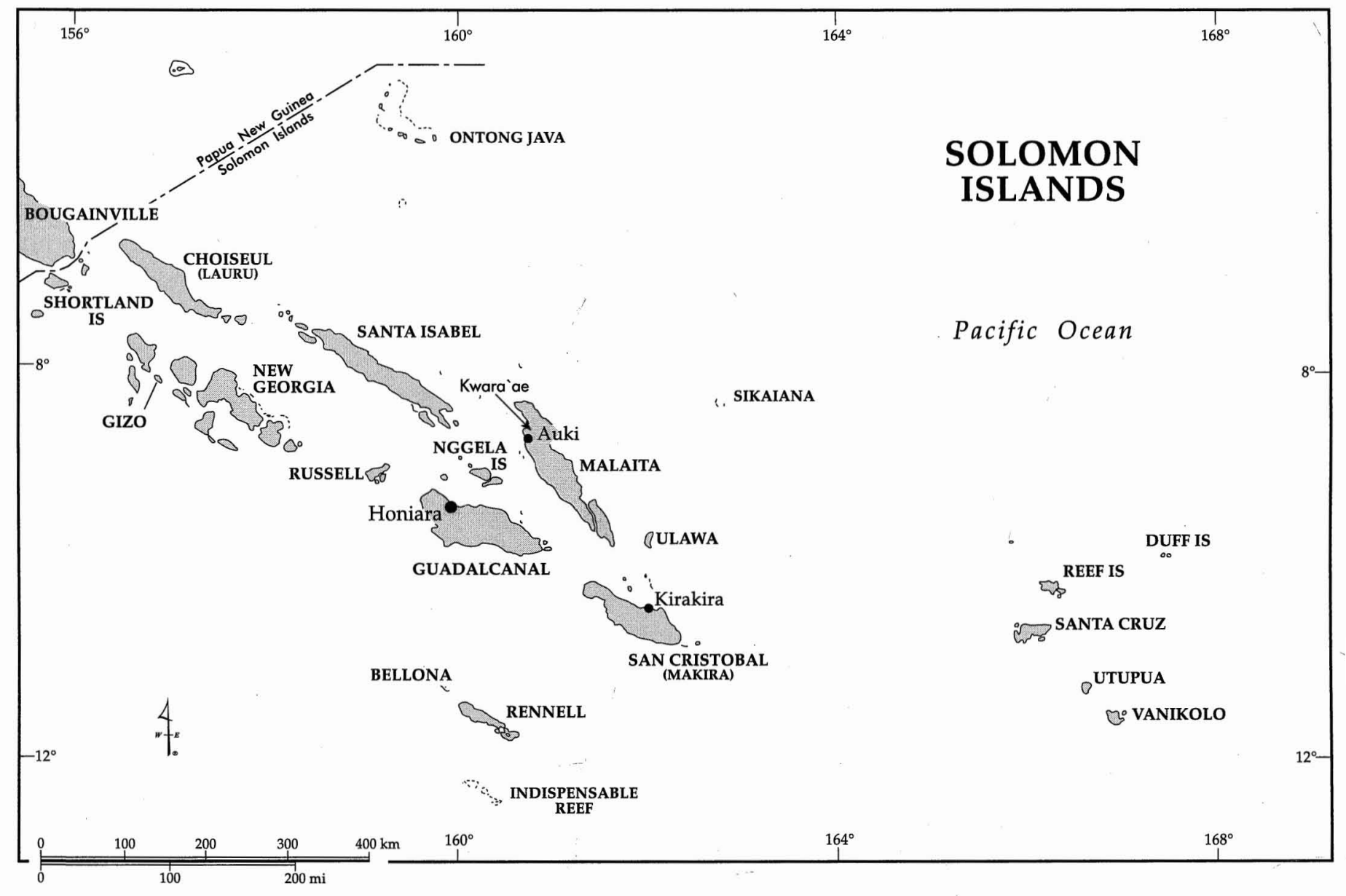

MAP I 
Watson-Gegeo and Gegeo 1992; Hobart 1993; Gegeo 1994, I998; Scoones and Thompson 1994; Warren, Slikkerveer, and Brokensha 1995; Pieterse and Parekh I995; Chapman I995; Brush and Stabinsky I996; Nader I996; Goebel I998; Hirtz I998; Keck I998).However, even the literature on local or indigenous knowledge focuses on people's existing knowledge, that is, knowledge already in everyday use and practice. The assumption behind this focus is that knowledge can be extracted from the knowers, treated as a text, and employed in a mechanical, instrumental manner-a conceptualization of knowledge consistent with the "container" metaphor in which knowledge is treated as content and human minds as individualized containers, a view made obsolete by current learning theory (Lakoff and Johnson I999; Resnick, Levine, and Teasley I99I). The extractive, textual nature of knowledge is an Anglo-European, top-down assumption congruent with modernization, even when applied by those critical of modernization. To the contrary, when villagers apply indigenous knowledge in development, they are involved in a process of constantly (re)theorizing, (re)creating, and (re)structuring knowledge. The Kwara'ae make a metaphorical distinction betweenintroduced knowledge and indigenous knowledge: introduced knowledge is knowledge "from the shore reaching out to the ocean" (knowledge that comes to the shore from the sea); and indigenous knowledge is knowledge "from the shore to the mountains." Once introduced knowledge becomes indigenized-(re)constructed and transformed to fit indigenous and local practices, experience, and culture-it is regarded by the Kwara'ae as indigenous although not "traditional" in the sense of coming down through history from ancient times. In the case of indigenized knowledge, people understand that they have taken something and made it their own, and that they now claim ownership of the knowing involved with this something; that is, it has become part of their knowledge system.

For rural villagers in cultures like Kwara'ae, their knowledge is encoded in the features of the environment, and development in the Anglo-European sense is unfamiliar to them. What has been missing from the development literature is systematic, careful examination of how differing indigenous peoples construct knowledge - that is, indigenous epistemology.

By indigenous epistemology we mean a cultural group's ways of thinking and of creating, (re)formulating, and theorizing about knowledge via traditional discourses and media of communication, anchoring the truth of the discourse in culture (Gegeo I994, I998; Gegeo and Watson-Gegeo 
200I; Watson-Gegeo and Gegeo 2002). Conceptually, indigenous epistemology is concerned with the process through which knowledge is constructed and validated, and the role of that process in shaping thinking and behavior. All epistemological systems are socially constructed and (in)formed through sociopolitical, economic, and historical context and processes. ${ }^{2}$ In writing about indigenous epistemology, we find our work parallel to the notion of standpoint epistemology as developed by feminists, which recognizes that " $[\mathrm{k}]$ nowledge claims are always socially situated" (Harding I993, 54) rather than universalistic. By this is meant that knowledge is created in a particular situation by a particular group of people. It may or may not be universalistic in nature, but it is always created situationally.

Elsewhere (eg, Gegeo I994; Watson-Gegeo and Gegeo I990; Gegeo and Watson-Gegeo 200I) we have written at length about Kwara'ae indigenous epistemological strategies used in such discourse events as village meetings, dispute resolution, and classroom teaching. Here we look in a more general way at how epistemological strategies are employed in a development project. Our interest in the collision of knowledge systems leading to various kinds of development failures comes from the first author's indigenous knowledge of Kwara'ae culture, and his observations growing up during a period of rapid, but failed, modernization-style development in West Kwara'ae during the I950s and 1960s. Our interest also comes from more than twenty years' research (from the late I970s through the I990s) on development and related aspects of social change in Kwara'ae, in which the issue of colliding knowledge systems repeatedly came to the surface.

Data for the case examined here include in-depth interviews with project participants and more casual conversations with other involved villagers conducted throughout the life of the project and especially in concentrated interviews in 1992, 1994, and 1998. Reported speech comes from interviews in which there was consensus among interviewees on key wording. Kwara'ae children are trained from the age of three to report the speech of others as accurately and fully as possible, because this kind of recall is essential to testifying in village meetings and especially court cases where reported speech is treated as important evidence and is subject to intense interrogation.

In analyzing the case presented here, our objective is not to lay out the details of knowledge construction, intersection, and mismatch, which 
would require a book-length treatment (but see an example analysis in Gegeo 1994). Rather, we want to provide a general overview of the collision of knowledge systems and the social fallout from that collision.

\section{Development on Malaita: A Historical Perspective}

Malaita is the least developed of the six major islands in the Solomons. The history behind Malaita's lack of development can be traced to colonial times when the British colonists judged Malaita-the most populated island in the Solomons even in the nineteenth century-as unsuitable for major agricultural development. This assumption derived from attempts to establish European-style farms with crops inappropriate for Malaita's shallow soils and heavy rainfall (Malaita is essentially rain forest). However, other potential development was never tried on Malaita because the colonial administration regarded Malaita's greatest asset as its abundance of hardworking male laborers who could be exported first to plantations in Queensland (Australia), Fiji, Samoa, and New Caledonia, and later to Guadalcanal and the western district of the Solomons for plantations established by colonists there. Historically, these laborers have worked for very low wages or have been paid in consumable items such as food and tobacco (Moore 1985; Bennett 1987), and so could not remit large sums back to Malaita with which to begin their own medium-sized projects. Colonial development was highly centralized and promoted the benefit of the colonial administration. ${ }^{3}$

Even after the Solomons became independent, the practices of the colonial administration toward Malaita continued. As a result, Malaita has provided most of the labor for national development in the Solomons, ${ }^{4}$ while Malaita itself has remained relatively undeveloped. The colonial and national governments have used Malaita for demonstration projects and training centers, but again, these activities do not bring much income or employment to Malaita and are insufficient as a base on which Malaita itself can develop. Training centers, for instance, have been governmentor church-subsidized and cannot even be taxed by Malaita Province. Similarly, Malaitans who are educated and in the professions (medicine, etc) have migrated off-island to other parts of the Solomons where urban centers and employment opportunities are greater due to centralized national development.

The need to create development opportunities for rural youth in the 
Solomons is critical. Children under fifteen years of age constitute 47 percent of the Solomons' population; nearly one person in five is under five years old (UNICEF I993). Since the I980s, schooling has been promoted as the way to help youth find jobs in the cash economy. Yet most children in rural areas fail or leave school by the end of their primary education, and even those who complete secondary find a very tight job market. In fact, the unemployment rates for senior primary school and secondary school graduates are equally high today, because of the scarcity of jobs. Educational disparities are great from one province to another, and between urban and rural areas. In some areas of Malaita, for instance, as many as 40 percent of children are not in school (UNICEF I993, 4I). About 63 percent of Malaita's total population has received no formal education, compared to 9 percent in Western Province, the latter being one of the focal areas of centralized development (Solomon Islands Ministry of Finance I990, 275). Nearly 40 percent of Malaita's teachers are untrained (Solomon Islands Statistics Office 1992). Malaita's students have the poorest record for gaining admission to secondary school-their percentage is about half that of the main urban center of Honiara (UNICEF I993, 46). The flow of Malaita's children into secondary school is inhibited by admissions policies that set limits for various ethnic groups and do not accommodate Malaitans' larger proportion of the total population.

When Malaita youths, especially males, ${ }^{5}$ fail to get into secondary school, the opportunities for them on Malaita are very few. They also suffer intense embarrassment from not having succeeded in school after their parents and kin invested scarce resources in their school fees (public education is tuition driven in the Solomons). As a result, for decades a large number of Malaita youth, mostly male, have drifted into urban areas in search of employment or because they are attracted by the "glitter" of urban life-exposure to cinema, international musics, and so on. Typically these youth with little education can find employment only in very temporary, casual labor situations; most find nothing. Many become involved in petty crime, alcoholism, drugs, and gangs. In town they are beyond the control and guidance of the extended family, and separated from their indigenous cultural roots.

Back home on Malaita in the villages, a number of projects have been designed locally to try to keep male youth on Malaita, give meaning to their lives, develop their skills for earning a living, and increase their sense of self-worth and cultural rootedness. We turn now to the specific case of a project so designed, the 'Oka Village Youth Project. ${ }^{6}$ 


\section{'Oka Village Youth Project: \\ Indigenous KnOwledge and Praxis}

In the early I 980 s, a cross-generational group of men in 'Oka village, concerned about the rising numbers of village youth migrating to other islands and urban centers (such as Honiara, the national capital on Guadalcanal) in search of jobs, formed a youth project to help keep youth home and give them a stake in the community. The project involved young men in sports, cultural activities, and income-generating work, parallel to the integration of sports, culture, and work in the traditional men's house of the past. They began with a club in which older members taught younger members how to play soccer and coached them in games, while a group of elders in their forties to seventies taught the young men about traditional Kwara'ae culture and dances. The club organized soccer tournaments in which teams in the area paid a fee to compete. During the matches, members of the club sold beverages and food to spectators to raise money. Similarly, club members learned and performed kastom (Solomon Islands Pijin: 'culture, tradition') dances for paying spectators. The elders realized that youths would be more interested in learning about tradition if it were tied to the exciting performances that traditional Kwara'ae dances involve, and if they could generate income from dancing. Together the soccer and culture dimensions of the project were simply called iut 'youth, youth group'.

The soccer/dance club was very successful, with its membership mushrooming almost overnight to involve more than a hundred young men (one of the largest villages on Malaita, 'Oka village has a population of several hundred people). The club decided to initiate a series of small additional projects to raise money. With each member contributing a membership fee of a few dollars, they collected sufficient funds to purchase a fiftykilo bag of white flour and an empty forty-gallon gasoline drum with which to make an oven. From this beginning they established a bakery and produced loaves of bread that they sold to the village. They earned enough from the bag of flour to purchase five more. Moreover, they used some of the first profits to buy seed to begin a Chinese cabbage garden. Then they went on to plant corn, pineapple, sweet potato, and peanuts.

Once these small projects were successfully underway, an elder suggested starting another activity:

I told the youth group that, even though the projects we currently were running were making money, we should not rely too much on them, knowing the 
way money circulates in rural areas. Some years there is good circulation of money... [and] other years the circulation is bad.

The group decided to use some of their profits to begin a copra project. As they did not have among them an established plantation of coconut palm trees nearby, they hired a truck to travel north some twenty-thirty kilometers to villages that produced copra but had no easy transport to the market in Auki. On the first trip they purchased thirty bags of dried copra, which they sold at considerable profit in Auki. This allowed them to fund another copra trip, and to open a youth club bank account in Auki. Some money they set aside to allow their club to participate in local soccer matches, some was devoted to savings, and some designated to cover the costs of the other income-generating projects. Moreover, they kept money in the village for youth club member emergencies. For instance, members already married might need cash in the middle of the night to hire a truck to take a child to the hospital. The club also performed a community service by loaning small amounts of money to villagers who experienced emergencies of their own, such as council taxes, trucks to the hospital, or school fees.

The club continued its small projects very successfully over several years, to the point of starting a rice project in the late I980s. As rice was a crop new to local villagers, the elders wrote a letter to the Japanese ambassador in Honiara asking for assistance. In the letter, the elders emphasized that they were poor rural villagers who wanted to do something for youth, and that the Solomon Islands government had not responded to several requests for help from the club. Two Japanese representatives then visited 'Oka village, and the youth club performed traditional dancing to welcome them. The representatives took the elders' letter to Japan, and subsequently a Japanese volunteer abroad was sent to assist the club in its rice project. A year later, a second Japanese volunteer was sent to work with the club for two years.

The success of 'Oka Village Youth Project in these early years was closely associated with its social organization and foundation in cultural knowledge. With regard to social organization, the project leadership was decentralized and egalitarian. First, leadership was not invested in a single individual nor even in a specific group; rather, it was shared among elders, middle-aged men, and youth according to the expertise and knowledge required for a given activity. Thus, a particular elder who was especially known for his traditional cultural knowledge of mao (a sacred Kwara'ae 
men's dance) led the teaching of Kwara'ae dancing. Several men with specialized knowledge in traditional agriculture supervised the gardens. Another man who had once run a local bakery in the village (using skills he had learned from the Chinese while working on a plantation off-island) taught everyone how to bake bread. Other men and youth who had been expert soccer players taught and coached the games. All decisions were made in group meetings regularly held by the entire cross-generational youth project membership.

Knowledge experts did teach, but authority was not centralized and decisions were not dictated from the top. Rather, relationships were horizontal and the education process was hands-on. The project was actionoriented and offered the opportunity for youths to interact equally with elders and middle-aged men in a mutually respectful relationship. The teaching/learning strategy could be characterized as legitimate peripheral participation in a community of practice: with learners beginning as recognized participants on the periphery of an activity and gradually moving to full participation in the center as their skills develop, and "learning as an integral part of generative social practice in the lived-in world" (Lave and Wenger I991, 35 ).

This mutually respectful relationship was also maintained by other group strategies. One of these was humor. Project members engaged in a great deal of joking and friendly teasing, which helped to downplay status and eased moments of tension when errors were made (for example, when someone performed a task incorrectly and attention was called to it). This is not to say that heated arguments did not occur from time to time within the project. However, as members knew from individual experience in previous projects, arguments and tensions needed to be dealt with openly and immediately. Moreover, as the elders later commented, often these conflicts were constructive because they reflected youths' struggling with their own identity growing up in a rapidly changing society. The point made by the elders parallels Childs' (2002) concept of "constructive disputing" in which diverse or competing positions are recognized and dealt with rather than ignored and suppressed. Because the youth project members were all from the same village, they saw each other constantly in daily life, and employed many of the strategies of amelioration and indirection that keep relationships among villagers as comfortable as possible. Members of the project were very self-conscious of these issues and discussed them publicly in project meetings.

Older members of the project used traditional fa'amanata'anga 'coun- 
seling' events and strategies to resolve intra-project disputes. Fa'amanata'anga literally means 'shaping the mind' ( $f a^{\prime} a$ is a causative prefix; manata the verb and noun 'think, mind'; and 'anga a nominative suffix), and is a general term for the teaching of knowledge and abstract skills. In its more specialized sense it refers to counseling in which intellectual instruction, interpersonal counseling, and conflict resolution occur simultaneously, serially, or independently (Watson-Gegeo and Gegeo 1990). Children are initiated into fa'amanata'anga events and the appropriate behavior during them by eighteen months of age in many families.

Club members carefully screened applicants and recruits who wanted to join, so that trust and respect were highlighted. The youths did not feel threatened by the adults in the project because they were all part of the same local community, and none had a hidden agenda beyond normal village politics (which everyone understood). They were all of the same socioeconomic status - as one adult put it, "We all live in thatched houses!" In fact, living in a thatched house was seen as a measure of people's commitment to doing something for themselves and the group, to improve the lives of all of them. None of them had relatives highly placed in the government or the church, in private business, or studying overseas, so they had to depend on their own labor. Most of the elders were illiterate, but even the youths had finished only a few years of primary schooling.

Given their levels of education, the only body of knowledge they felt comfortable using, until the initiation of the rice project, was indigenous knowledge; and the only epistemology they knew for developing new knowledge out of their experiences was indigenous epistemology. Moreover, the epistemology they employed for the application of knowledge was itself indigenous. The distinction we are making here is between epistemology as a theory of knowledge, and epistemology as a theory of the application of knowledge. This distinction is important because of the later causes of the demise of the project.

The strategy of beginning one small agricultural project after another following on the initial success of the first is based on indigenous forms of agriculture, whereby diverse crops are raised together simultaneously. In Kwara'ae, the term for this is fasidoladola'anga 'the planting of different crops together; mixed cropping' (lit., fasi 'plant'; doladola 'mix'; 'anga nominative suffix). More than that, this strategy is anchored in the indigenous concept of diet. Adami'anga 'the eating of a variety of foods in the same meal' is the Kwara'ae concept of a holistic, balanced diet (WatsonGegeo and Gegeo 1985). 
It was no accident that after the club used its initial profits from soccer and mao performances to start a bakery, members went on to begin agricultural activities, including planting gardens, transporting and selling copra, and then initiating a rice project. First, they were diversifying to make effective use of the variety of expertise within the group. Members felt strongly that the only way the club would prosper was to take everyone's expertise into consideration so that everyone had a role, as in a family. In fact, the members referred to the youth project metaphorically as a "family."

Second, they diversified to ensure that the growth of a given activity remained within their ability to manage, and alternatively, that failure of one or two activities would not bring down the whole project. These two considerations are based on people's knowledge and practices in subsistence gardening. The first consideration is referred to in Kwara'ae as kwaisaefafi ${ }^{\prime} i$ 'see something at eye level' (lit., kwai is a reciprocal prefix; saefafi $i$ ' 'manageable'), as opposed to lia 'ala'a 'look up [beyond one's reach]'. Epistemologically, kwaisaefafi ${ }^{\circ}{ }^{\circ}$ anga (the noun form of the word) refers to the relationship between the knower and the known, that is, object of knowledge (see the discussion of "epistemic horizon" below). The second consideration is illustrated in people's practice of planting several gardens, each in a different location (valley, ridge, mountains) as a hedge against crop failure from drought, storm, or pests.

The third and equally important reason for diversification was the comfort level project members felt with agriculture. In Kwara'ae indigenous epistemology, a distinction is made between diflopmen 'development' and bisnis 'business'. Diflopmen is seen as a mode of operation promoting life in line with the Kwara'ae philosophy of gwaumauri'anga, which embraces the notion of 'the state of being at the head or pinnacle of life'. More specifically, it refers to the ideal state of ali'afu'anga 'total completeness', where mauri'a 'life', and mauri'anga 'the process of living', involve happiness, security, plenitude, and the key cultural values of love, peace, and sharing (Gegeo I998). Diflopmen is seen as "alive" in contrast to bisnis, which is seen as "dead." The most important distinguishing characteristic of diflopmen in this respect is that a project so labeled saka ma'i māna or fa'asia limana ngwae 'emerges out of one's own hands'. Moreover, most projects labeled diflopmen actually involve "products" that are living.

Bisnis, in contrast, is seen as a "dead" or "inactive" mode of production concerned only with material possessions. It is also seen as external to oneself and not emerging from one's hands. In the case of, say, store 
goods, the goods themselves (eg, tinned fish) are actually dead, and therefore their only value is monetary. More importantly, bisnis is "dead" because it involves introduced activities-such as a bakery-that come with their own body of knowledge and epistemology. For rural people, that body of knowledge is still in the realm of "information" rather than "knowledge." When a Kwara'ae villager talks about a bakery, that person's knowledge is soon exhausted, and what it takes to start a bakery is out of the immediate control of the would-be owner because it entails purchased items such as the ingredients and aluminum sheets for kneading and baking. In contrast, diflopmen is "alive" because carrying out its activities requires indigenous knowledge rather than outside information; people have been subsisting by agriculture in the Solomons for thousands of years. When Kwara'ae villagers talk about gardening, it is almost impossible to exhaust their knowledge and ability to theorize. They feel less comfortable engaging in economic activities they consider bisnis rather than those they see as diflopmen. It is not surprising, therefore, that although the youth project started with a bakery, which is seen as bisnis and therefore "dead," it soon moved on to agriculture (gardening, copra, rice).

\section{'Oka Youth Project Encountering Village Politics}

Even before youth project members appealed to Japan for help, they began to encounter attempts by others within 'Oka village to take over their project. A large group of village chiefs, elders, and other men made their argument on both indigenous and introduced grounds. From an indigenous perspective, they used expressions such as, "It is fitting that we all cooperate and do things together as people of one village." They conceived of the project as kamiuniti 'community, community development' and argued that, now that the project was redefined as community development, the next step was to ensure that its money was safe, which meant they should start a community credit union, followed by a general store.

During a village-wide meeting, youth project members questioned community development supporters about their motivation for "collapsing" (as youth project members saw it) the youth group into a village-wide project. They pointed out that such large-scale local projects had been tried several times before in their area, and all had failed. Nevertheless, the village chiefs invited one of the leaders of a previously failed project to come to the village and set up a credit union. When youth group members con- 
tinued to resist having their project absorbed into the community development effort, other villagers began to ridicule them as an "aging youth group" (because the membership included elders and middle-aged men as well as youth).

The youth responded to these chiding remarks by arguing that elders were members because they were part of the original cross-generational vision of the youth group, possessed traditional knowledge, could handle the hard labor tasks that the youngest members could not, and brought skills beyond soccer-skills needed to make the project grow. Additionally, as youths, several of the elders had been involved in failed large-scale projects directed by outsiders using a modernization paradigm. They had insight into the causes of these project failures. Most particularly, they rejected outsider explanations attributing project failure to traditional cultural practices. Rather, according to their analysis, earlier project failure was the result of applying Anglo-European knowledge and strategies with which rural people were unfamiliar and that were inappropriate to local culture and environmental conditions. Moreover, the youth argued that the aims of the youth project were educational, not just money-making like the community development effort. In that respect, the community development effort was unquestionably modernization rather than development.

Concerns about the pressure being put on them led elders in the youth project to visit the provincial government headquarters in Auki, to seek information about running village projects. However, they rejected what they learned there. As one later said:

We decided to stick with our original idea of running the youth group according to the egalitarian and consensual way things were organized and done in kastom [because] after we had studied [the provincial guidelines], we decided it was irrelevant to our purpose.

This was the point at which the youth group, wanting to start a rice project, appealed for assistance to the Japanese government, having had their requests to the Solomons government turned down. They felt the need to incorporate outside information about rice-growing into their indigenous knowledge of agriculture because, although rice is a highly popular food item on Malaita, they had not grown it before. The land they wanted to use was swampy and unsuitable for local varieties of taro and sweet potato, but suitable for rice. They saw the help that the Japanese could provide as information and skills, not "knowledge." "Knowledge" was 
what they would develop themselves from experience growing the rice. This view is an indigenous perspective on knowledge, in which knowledge involves expanding on and (re)constructing information and skills.

During the middle years of the 'Oka Village Youth Project, in the discourse of the argument between project members and the other villagers who were attempting to absorb the project, the terms iut and kamiuniti were used for youth group and community development, respectively. Semantically, these two terms entailed meanings that contrasted indigenous with introduced values and ways of operating.

Specifically, iut connoted a focus on youth, but also doing things that were under one's control using primarily indigenous knowledge and indigenous epistemology. That is, the activities were within villagers' epistemic horizon. Although we use an English label here, the concept comes from Kwara'ae. Liatau'anga refers to 'seeing far', that is, always seeing the horizon at a distance and never reaching it (Gegeo and Watson-Gegeo 200I). The Kwara'ae notion of epistemic horizon is that one is motivated to do something when one is able to see far ahead. And in doing, one experiences a growth of knowledge. Seeing distances is itself epistemological because it involves theorizing. Epistemic horizon implies that there is no barrier or cloud between the seer and the horizon, and that everything in between can therefore be seen clearly and is within one's knowledge grasp. Questions arising were less "How do I do this?" than "How much of this should I do?" All is within one's reach as one continues to build on the already known.

In contrast, kamiuniti connoted nonindigenous ways of organizing activities, the distancing of relationships, large-scale projects, a concern exclusively with material gain, and introduced knowledge and epistemology. Epistemologically, it thus connotes activities and knowledge outside villagers' epistemic horizon. In fact, "community development" as understood and used in 'Oka village during this time conveyed the notion of tuamalafaka'anga 'pseudo-westernization'; literally, 'living in imitation of life brought by the ships' (Gegeo 1994, I998). Members of the youth group, especially those who were adults in the I940s-I960s, had individually and collectively experienced a great deal of that kind of community development. Like all large villages in Kwara'ae, 'Oka village itself had been founded on the framework of tuamalafaka'anga: it consists of several clans that moved to the coast from the interior as they were converted to Christianity and as they sought access to outside trade. 
The youth group saw itself as founded on an alternative conceptualization and praxis, as members believed that it was precisely the desire and attractions of tuamalafaka'anga that were luring youth away from villages into urban areas, with the attendant involvement in greater poverty, crime, and other problems. Members deliberately avoided using terms like bisnis or diflopmen in their project to emphasize that their vision was differentthat it was anchored in traditional culture, drawing on the positive aspects that could prepare youth for today's changing world. Indeed, the Kwara"ae have an indigenous concept equivalent to "development" in the holistic sense, as encoded in at least thirty-two terms which discuss its characteristics (Gegeo I994, 299-300), for example: talau'anga 'being on one's own', literally, 'following the path cut by oneself and doing things one sees fit to meet one's purposes and needs'; bulaofaolo'anga 'growing anew'; lafuta'ilana tua' $a$ 'the lifting or rising up of the family' from the inside; fuliru'anga 'establishing things (not just talking about it), bringing to fruition'. This set of concepts formed the core of the vision for the youth group. More importantly, they were terms in the youth's indigenous language and within their epistemic horizon, such that they understood the terms and their meanings and knew how to apply them, in contrast to introduced English terms like independence, self-sufficiency, and self-reliance, which formed the core of community development terminology introduced into Kwara'ae by previous failed projects. The Kwara'ae youth group's reactions to and frustrations with such English concepts paralleled those reported by Hanlon (1998, I43) for Micronesians in the I970s, who experienced "larger epistemological doubts" in trying to translate modernization terminology into local languages.

It is particularly telling that the first new activities supporters of the community development vision wanted to introduce- a credit union and a general store-were activities that had repeatedly failed in modernization efforts in West Kwara'ae. As an elder put it during a tendentious village meeting over the youth project's future, "Have you people still not seen? We are merely repeating things that we have tried and that have failed." General stores and credit unions also fit into the Kwara'ae indigenous conception of "dead" rather than "alive" types of projects. ${ }^{7}$ As pointed out above, items in a store are seen as "dead" because they were produced by someone else and are literally dead. A credit union is "dead" because money itself is literally dead. A metaphor used locally is that one cannot toss a dollar bill onto the floor of the forest and expect it to sprout 
like a potato vine. Moreover, the growth of money in a credit union depends on other money villagers put in. Given the level of poverty in the villages, growth is extremely slow. Further, unlike plants in a garden which can be seen to grow week by week, monetary growth is invisible to the eye, and so is not motivating to villagers. Credit unions are also seen as "selfish" and "discriminatory" because they depend on individual wealth; those who already have money benefit most.

\section{'Oka Youth Project, Jack Tagi, and the Collision of Epistemologies}

Three years after the 'Oka Youth Project faced its first challenges from community development supporters, Jack Tagi retired to 'Oka village from his years as a government official directing a major financial institution in Honiara. He was already known to side with the community development contingent in the village. Tagi called a village meeting during which, on a blackboard borrowed from the local school, he drew what he called a new structure for a community development project, pointing out how it would operate to everyone's benefit. He claimed to be able to write large, professional grant proposals to outside sources that would pull in much greater sums of money than the youth group could ever expect to attract.

This was the first of several village meetings in which Tagi and his supporters attempted first to persuade, and then to force the youth club to merge with the proposed community development project. Many of these meetings involved heated exchanges between Tagi and his supporters on one side, and members of the youth project on the other. Tagi argued, "Do you know anything about finances and management?" He emphasized his education and years of experience in government-organized development. The youth group challenged Tagi's "new structure" as identical to that of a well-known failed project involving 'Oka village a decade earlier. They countered that he was "blinded by [his] western education." In one passionate speech, a youth group member said:

For many years you held very important positions in businesses in Honiara [but] you never once came over to our village to ask if we villagers wanted any assistance with development projects. As a result we never looked to you for help. When we wanted to do anything in the village, we had to do it through our own struggles. Who gave you the right to force us to collapse ['asi 'fall'] the youth group into a community development project? You have just arrived in the village [after being away for years]. 
Not long after these initial meetings, two Japanese officials arrived in the village to assess the success of the youth project so far, with the intent of continuing to support it. Tagi drew them off to his house and convinced them that the youth group should merge with the community development effort. He then called a village meeting to announce this change to everyone. In the ensuing meeting, one of the youths in the project angrily said:

You are very stubborn, aren't you? We told you we did not and still do not agree with the merger ['adofiku 'join'] you are proposing. We have worked very hard, starting with nothing, to create our youth group, and now you and your allies are telling us that we must merge with community development. You all have tried so many community development projects in this village, and nothing ever came of any of them. Whatever happened to the village credit union that you all were so proud of? Why didn't you, Tagi, do something about that? This is our youth project. Stay away from it. Why don't you, with your European [ara'i kwao 'white man'] knowledge that you are so boastful about, raise that credit union from the dead?

The same youth turned to the Japanese representatives and interrogated them: "I want to ask you two a question. Who brought you here? Was it the community development project or the youth group?" One of the Japanese responded, "The youth group. We came as a response to the request for assistance made by the youth group." The youth turned back to the other villagers:

Did you all hear that? Let me tell you, Tagi, if you and your supporters want a community development project, resurrect the credit union. You are not touching our youth group. Our eyes are open.

The Japanese representatives attempted to convince youth group members to merge with the others, but were unsuccessful. When Tagi's supporters again raised the issue of Tagi's greater education, another member of the youth group, an elder, responded:

We in the youth group do not need any highly educated person meddling in our affairs. We do our planning according to how we know; our plans are local [ie, indigenous ways of knowing and doing]. They cannot be turned into your high [Anglo-European large-scale] plans. You have no experience with local planning. Local planning is a different thing altogether. It has its own power [ngasingasi'anga 'power, efficacy'] ... Do something in which you can apply your experience in high-level planning. We will stay with our project which seems to be doing just fine being run according to our local plans. 
Nevertheless, Tagi formed a village committee to start the community development project, and tricked the youthful treasurer of the youth project into loaning him money to purchase a chain saw. He attempted to bribe members of the youth club to join him, by taking them to Honiara, paying for their fares and accommodation out of his own money, and showing them different businesses in Honiara that he claimed he could bring to 'Oka village with his knowledge and skills. Then in a manner that no one was subsequently able to figure out, Tagi managed to get control of the youth project's bank account. He may have misrepresented himself to the bank as a youth club leader, and given his social standing in the nation and community, he would have been believed. Once the monetary resources of the youth project were in Tagi's hands, the project's days were numbered.

Youth project members still attempted to resist, however. For example, Tagi wrote to the Provincial Development Unit (PDU) office in Auki, claiming that the rice project belonged to the community development project, and requesting a loan of SI $\$ 75,000$ (US $\$$ I 8,750 at the time) to expand it. When youth club members found out, an elder intervened at the PDU office, which at his request sent an official to examine the project. The official ascertained that the rice project should receive only si $\$ 40,000$ (us \$IO,০o0) for expansion. In reality, however, Tagi's intent (which he himself stated publicly) was not to expand the rice project at all, but to use the si $\$ 75,000$ to turn the local primary school into a church-affiliated technical training center. When Tagi learned that the elder had intervened and was partly responsible for the failure of his loan plan, he threatened to take the elder to court. The elder responded during a village meeting:

Go ahead and take me to court! I have nothing to lose or gain. I am just an ignorant villager who stood up for the right of the youth group. ... If we the ignorant village people do not stand up for our rights, our own so-called educated people will push us around. They will use the court as a way to keep us silent and force us to go along with their ideas.... What Tagi is doing to our youth group is like a hunting dog that has caught an opossum and has brought it to its owner. Instead of sharing some of the meat, the owner beats the dog and eats all the meat [a well-known Kwara'ae metaphor].

Despite the attempts of the members of the youth club to hold onto their project, they faced constant verbal assaults in village meetings, and they were significantly outnumbered. Some of the youths' parents began to ally themselves with Tagi because of his wealth and social importance; many 
were involved in an effort to get him elected to the national Parliament at this time.

Over the course of a couple of years, the members of the youth group became disillusioned.They soon found themselves spending more time and effort defending themselves than working productively in the project. A cost-benefit analysis, local style, led them to give the project up altogether, once attendance at project meetings began to drop, and the youth themselves began drifting off to Honiara - the very problem that the project had been intended to prevent.

Ironically, Tagi and his supporters also experienced failure. Their project soon collapsed, much more quickly than the youth project, which had lasted about a decade. Tagi also failed in his election attempt.

Tagi's was an Anglo-European, modernization vision of what the village project should be. He rallied behind him factions of the village who felt that the project should serve the whole village, not just youth. His intention to fund the project by outside grants introduced dependency on external aid, whereas before the youth club project had been "in our own hands," as one member put it. Even for the rice project, the Japanese government had provided support only in the form of Volunteers Abroad who trained project members. All of the rice-growing expenses were paid by project members themselves.

From an indigenous epistemological standpoint, Tagi's trips to Honiara were seen as ngwasinasina 'flashy'. This behavior was "letting too much light [into one's social space]," that is, attracting too much public attention, given the stage youth group members felt they were at in building their project. In other words, as with many other things Tagi did, his actions took the project several steps beyond the members' current epistemic horizon. One Kwara'ae expression used by youth club members for this behavior was lofoliunga'inia 'jump over several logs', rather than take one log at a time. What Tagi was attempting to do, of course, was give the project public visibility-an Anglo-European business notion. However, visibility in this sense runs counter to Kwara'ae cultural practices.

Tagi also restructured the project leadership, claiming, "Now your project is big and you need people with education. I can provide that leadership." Making a statement of this kind is also seen as "flashy" because in Kwara'ae one does not put oneself forward; instead one must be invited. Tagi tried to vest all leadership in himself, a highly centralized and nontraditional approach. His leadership was top-down, command style, and he made most decisions with little consultation with others. He also set up 
an office in his western-style permanent house in the village, and later he rented an office in Auki, the urban center and provincial headquarters on Malaita. The appropriate indigenous approach, however, would be to have no office, but rather to meet in people's homes or the village meeting house. By local standards, Tagi's style was arrogant and boastful in contrast to the preferred Kwara'ae style of humility. As a result, people said that his leadership "brought darkness."

People either had no experience at all with the activities Tagi proposed for project expansion, or had previously failed at them. These were projects beyond people's epistemic horizon-beyond not only their epistemology for developing new knowledge, but especially for applying knowledge. The question was no longer, "How much of this should I do?" Rather, Tagi might say to someone, "Do the accounting." The question would then be, "How does one do accounting?" The difference here is between "How much should I apply my knowledge?" and "I don't have the knowledge I need to apply, and do not even know where to begin in order to learn." It is the difference between trying to tackle an impossible task, and being helped to learn through "legitimate peripheral participation" in a community of practice, where learners have considerable agency in how and what they learn, and they themselves create new knowledge-as had been the case in the youth project.

Similarly, in contrast to Tagi's approach with outside aid and learning, what the youth project had accomplished by receiving help from Japan was to be able to work side-by-side with the two Japanese volunteers, and to learn via legitimate peripheral participation. The villagers listened to the Japanese volunteers and followed their directions as to how rice is grown in Japan. But even as they were following these directions they were already thinking about how the techniques would need to be altered to fit the local environment, local schedules, and other contextual factors. They were observing the progress of the rice sections they planted, which ones performed better than others, and comparing their observations with previous attempts to grow rice in the immediate area as well as with experiences planting other introduced crops. In West Kwara'ae villages over the past two decades we have often watched this process of trying out introduced techniques and altering them based on the observation and application of indigenous knowledge.

Villagers are pragmatic and oriented toward action. For them, learning involves doing and then drawing theoretical abstractions from the doing. 
In other words, within indigenous epistemology, Kwara'ae villagers engage in indigenous critical praxis, critical reflection on culture, history, knowledge, politics, economics, and the sociopolitical contexts in which people themselves are living their lives; and then take the next step of acting on these critical reflections (Gegeo and Watson-Gegeo 200I). The debates in village meetings between members of the youth project and other villagers, including Tagi, illustrate the outcome of indigenous critical praxis among project members, who had learned not only to critique modernizationstyle development, but also to use those critiques creatively in their own designing and work in the project.

The strategies that Tagi used to attempt to resolve conflicts between his supporters and members of the youth project were part of his community development model. Rather than using indigenous strategies of resolving conflict, such as fa'amanata'anga as used by the youth project, he introduced a religious testimony approach. On Sunday mornings at the end of the church service, he would ask the priest for permission to go up the steps to the front, face the congregation, and give testimony regarding a conflict that happened that week between the two groups or individuals in the village. Then he would invite representatives from both sides to each give their own short testimony. After this, he told all of those who spoke to hug each other and weep. This style of conflict resolution was, of course, introduced by the missions, especially the more evangelical sects. Everyone in the village felt uncomfortable dealing with project disputes in this way. First, Kwara'ae is not traditionally a "hugging" society; shaking hands (another introduced behavior) is acceptable, and traditionally the exchange of food or other items would be involved in dispute resolution. Elders in particular felt uncomfortable with Tagi's strategies, as well as any women who had engaged in the village debates, because cross-gender hugging is customarily prohibited. The more appropriate indigenous strategy, if the church was involved, would be for the parties in dispute to visit the pastor or priest, or invite him to one of the homes, for a private reconciliation. Secondly, villagers felt that the sanctity of the church was violated by the testimonial kind of behavior around a secular issue, especially because there was a culturally prescribed appropriate context for disputes to be settled. In the context of the church, Tagi's idea was that God and everyone else would witness the reconciliation so as to seal the outcome once and for all. But many said, "What has God got to do with a village dispute over a rice project?! It's a secular issue." 


\section{Discussion: Whose Knowledge?}

The 'Oka Village Youth Project case presents us with important lessons about village factions, introduced versus indigenous knowledge, villagers' agency, and broader issues in rural education.

While conflict over land and resources throughout Malaita seems to be intensifying with population growth and modernization, the underlying causes of the 'Oka conflict had particular historical roots. 'Oka village was a product of missionization that lumped several clans and descent groups of varying sizes, seniority, power, education, and wealth into one unit. Because of long-standing disputes among village factions, it was susceptible to the kinds of power plays Tagi was adept at directing. Two decades before, another senior line had taken over, and ultimately destroyed, a similar local development project. Most of the time factions in the village do manage to get along. Tagi was leader of the largest and most senior ranked clan in the village, whereas the elders who were part of the 'Oka Village Youth Project were members of a smaller and much more junior descent group. The youth project elders tried to maintain their agency in the face of Tagi's challenge partly by claiming connection to another senior kin line outside the village-who willingly accepted the claimed link, but who could not intervene in the 'Oka village dispute because the land on which 'Oka village is built is not theirs.

As we have seen, the 'Oka Village Youth Project succeeded and grew so long as its members were able to guide their activities using indigenous knowledge and epistemology. It is important to emphasize that youth group members were not totally opposed to introduced knowledge. Rather, they knew that down the road as the project expanded, they would want to move into new, income-generating activities, such as the rice project they began about five years into their efforts. When they were ready for the rice project, they did not hesitate to seek outside guidance, and welcomed the Japanese volunteers who came to assist them. But the point is that in tackling these new activities requiring introduced information, they would grow from experience gained through activities that they already knew something about. One of the phrases they used to describe the project in its early years was that it was like sukulu'anga 'schooling': it was their way of getting an education. Although they used the Solomons Pijin word sukulu, they did not mean Anglo-European classroom learning. Rather, they used sukulu to mean the process of theorizing and creating knowledge-what we referred to earlier as indigenous epistemology. Their 
project was rooted in indigenous epistemology and indigenous knowledge as the fuli 'foundation' and to 'ofuna 'essence' of their work.

The 'Oka Village Youth Project illustrates the importance of indigenous knowledge and indigenous epistemology for manageable and significant development in rural areas of the Pacific Islands and in the Third World generally. We agree with Nyerere and others (I990; see opening quotation) that adapting new technological advances is important as part of an overall development plan in countries like the Solomons. But rural village-level development has a better chance of being sustainable, meaningful, and directly pertinent to people's immediate needs if it is grounded in their knowledge systems, as argued by Brohman (1996; see opening quotation) and many others recently. In the context of rural areas in the Solomons, this is certainly what villagers want, as members of the 'Oka Village Youth Project emphasized in interviews (see also Chaudhry 1999 for a parallel case). As Kwara'ae villagers often say, "I want a rural development model that will help me do something for myself here in the village, because this is where I am going to live and die." Introduced models, ironically even those purporting to anchor villagers' lives in the village, have only encouraged people to leave the village. That is because they teach people an introduced body of knowledge and a set of skills that are neither suitable nor relevant for the local environment (whatever outside experts may think).

However, knowledge itself, whatever its source, is not enough to ensure success. Villagers' agency is also essential. When Tagi took over the project and reorganized it, he disempowered villagers and the project ceased to be their own. The youth group members had collectively given birth to the 'Oka Village Youth Project out of their own planning and agency, and when Tagi intervened, they felt he killed the project. They had identified with their project as part of themselves, something from which they were learning, something that empowered them. His top-down management meant that project members went from working together like family members to being laborers, plantation-style. The youth group members were sensitive to this kind of labor organization. For elders in the project, it was a replay of their colonial and plantation experience.

With regard to broader issues in rural education, the failure of national schooling in the Solomons has been well documented (Watson-Gegeo and Gegeo 1992, 1994). The schools, with their emphasis on Anglo-European knowledge, inevitably prepare children for urban lifestyles and expectations. As most children fail or drop out of school after the early primary grades, they return to the village ill prepared for the rural life they must 
lead. The 'Oka Village Youth Project was an effort to mitigate the negative influences of schooling that the youths, like many of the adults before them, had experienced; and to prepare the youths for a productive village life. The model of "community development" that Tagi and his supporters brought was, like national schooling, based on urban expectations and lifestyles. Rather than prepare youth for village life, it would only have encouraged them to eventually leave the village in search of more appropriate contexts in which to use their new skills and fulfill the new expectations they had developed. In contrast to national schools and Tagi's modernization version of community development, the 'Oka Village Youth Project members themselves were going to be responsible for their education, rather than being passive recipients and having education, knowledge, or information merely "deposited" in them, along the lines of Freire's (1970) critique of the "banking model" of education. This understanding is part of the saka ma'i māna 'emerge out of one's own hands' perspective in Kwara'ae indigenous epistemology with regard to diflopmen.

\section{Conclusion: The Outcome of "Community Development"}

The self-definition of "indigenous" by and for indigenous peoples is related to the presence of strong communities that can ideally and materially offer sustenance to their members while also being able to reach out to others from their positions of strength. ... The ways in which native peoples are giving form to the word "indigenous" so that it can do good work in the world should be cause for celebration rather than condemnation. After all, recognition of multicultures enriches. (Childs and Delgado-P 1999, 2 I2)

Tagi and his supporters' orientation to "community development" was entirely economic, with no consideration for the problems of the youth. Adult members of the youth project argued, "How would a credit union keep youth in the village? They are restless and need something to be involved in physically." Tagi's vision also did not include the growth of knowledge on the part of participants, an aim that had been important to youth project members. Moreover, Tagi was interested in modernizing the village, not in encouraging youth to learn traditional culture. Ironically, the emphasis on modernization was guaranteed to encourage youth to leave the village for town, because it would increase rather than diminish their taste for Anglo-European lifestyle.

The failure of the 'Oka Village Youth Project due to Tagi's intervention 
is bad enough. What is worse is what happened to the youths who were displaced. Feeling disempowered and disillusioned, most of them drifted to the urban center of Honiara, adding to the escalating unemployment rate of urban youth. Then, more recently, when the ethnic conflict led Malaitans living on Guadalcanal to form a militia, large numbers of 'Oka village youth joined. They were in the front lines of the worst fighting. Now that peace negotiations have seemingly halted the conflict, and 20,000 Malaitans have been driven back to Malaita, one wonders what will happen to these youth. Now that they have experienced the power that violence and guns can bestow, it is hard to imagine them fitting into village life again. And yet the final resolution of the conflict is likely to include restricting Malaitans from Honiara and Guadalcanal.

Our intent here is not to overly dramatize the tragedy of this case, or to romanticize village life. Our purpose has been to substantiate with data from a real case the arguments theorists have made about the importance of indigenous knowledge in development. Particularly, we have tried to show that it is not just indigenous knowledge that matters, but how that indigenous knowledge is theorized and constructed, and how it is applied-indigenous epistemology together with indigenous critical praxis. In contrast to a "rural development" guided by outdated modernization models and ideas, development that is meaningful to rural people must be built on knowledge resources villagers already have, and the strategies they know for expanding that knowledge.

We ARe Deeply grateful to the members of the 'Oka Village Youth Project who gave their time in interviews in support of our work on rural development and indigenous epistemology.

\section{Notes}

I Examples of Pacific peoples who are still colonized include Kanaka Maoli (Native Hawaiians), Māori (Aotearoa [New Zealand]), Aborigines (Australia), Tahitians, and the Kanaks (New Caledonia).

2 Our thinking about indigenous knowledge and epistemology has been greatly enriched by conversations over the past several years with Stephen T Boggs and John Moffat Fugui, to whom we are grateful.

3 Other island groups that were also excluded from colonial centralized devel- 
opment include Santa Isabel, San Cristobal (now Makira), and the Santa Cruz islands (now Temotu Province). These island groups are rich in natural resources and have small populations; they could have been developed had development in the colonial British Solomon Islands Protectorate been less centralized.

4 Since the early twentieth century, colonial and national government labor and development policies have encouraged Malaitans' outmigration to Guadalcanal and the western Solomons. At the time of the onset of the ethnic conflict on Guadalcanal in 1998 , thousands of Malaitans were living on Guadalcanal, many of whom had been born there. The presence of a large number of Malaitans on Guadalcanal, some as legal land owners and others as squatters, was one factor in the conflict.

5 We emphasize male youth over female youth because young women still play traditional roles in the home. This is not to say that young women are necessarily satisfied or happy. But typically when young women fail or drop out of school, they take up female roles in the household and then marry within a year or two. With the loss of the traditional men's house since missionization, young men have had no clear social role in their household of birth. Instead, it has become customary for young men to go off island for employment for a few years before returning home (if at all) and marrying. Many young men and women do not wish to marry so early but see themselves as having little other choice for a meaningful life, given the lack of educational and employment opportunities. Early marriage has increased population growth on Malaita; it also feeds into rural poverty, because couples are not financially prepared for the many children they inevitably have due to inadequate birth control methods and church doctrines and cultural proscriptions against birth control. Modern medicine also means that nearly all pregnancies go to term, and nearly all children born survive to adulthood. The foregoing points illustrate how issues are complexly entailed on Malaita. Although a fuller discussion is warranted, it goes beyond the scope of this article.

6 All names are pseudonyms.

7 The credit union was seen as "dead" partly because it was conceived as a way to make money. When the credit union movement came to Kwara'ae in the late I970s, it was presented by outsiders as an alternative way of increasing wealth and speeding up development in rural areas. The convenience of a villagebased source of loans for illiterate villagers was also idealized, and anticipated "interest rates" were exaggerated. In contrast, although also seen as "dead," banks have long been established in the Solomons, and because their interest rates are canceled out by service fees on the small accounts villagers might hold, they are seen by villagers simply as places to keep one's cash securely. Most villagers consider banks far safer than village credit unions, which in their experience have all failed, with the result that members lost their money. Much more could be said 
here from a Kwara'ae standpoint. However, the point we want to make is that the variable history of the credit union movement in the rural Pacific illustrates the power of context, that is, of local conditions in determining the success or failure of ideas that seem on the surface to be inherently "good."

\section{References}

Apter, David E

1987 Rethinking Development: Modernization, Dependency, and Postmodern Politics. Newbury Park: Sage.

Bennett, Judith A

1987 Wealth of the Solomons: A History of an Archipelago, I800-1978. Honolulu: University of Hawai'i Press.

Brohman, John

I996 Popular Development: Rethinking the Theory and Practice of Development. Oxford: Blackwell.

Brush, Stephen B, and Doreen Stabinsky, editors

I996 Valuing Local Knowledge: Indigenous People and Intellectual Property Rights. Washington DC: Island Press.

Burkey, Stan

1993 People First: A Guide to Self-Reliant, Participatory Rural Development. London: Zed.

Cernea, Michael M, editor

I99I Putting People First: Sociological Variables in Rural Development. 2nd ed. Washington DC: World Bank; New York: Oxford University Press.

Chapman, Murray

I995 Island Autobiographies of Movement: Alternative Ways of Knowing? East-West Center Reprint 3I4. Honolulu: East-West Center.

Chaudhry, Lubna N

I999 Perspectives on Education from Field-Work in Southern Punjab, Pakistan. Paper presented at the South Asian Conference on Education, University of Delhi, I4-I 8 November.

Childs, John Brown

2002 Transcommunity: From the Politics of Conversion to the Ethics of Respect. Philadelphia: Temple University Press.

Childs, John Brown, and Guillermo Delgado-P

I999 On the Idea of the Indigenous. Current Anthropology 40 (2): 2 I I-2 I 3 . Connerton, Paul I989 How Societies Remember. New York: Cambridge University Press. Freire, Paulo

1970 Pedagogy of the Oppressed. New York: Continuum. 
Friedmann, John

1992 Empowerment: The Politics of Alternative Development. Cambridge, MA: Blackwell.

Gegeo, David Welchman

I994 Kastom and Bisnis: Towards Integrating Cultural Knowledge into Rural Development in the Solomon Islands. PhD Dissertation, University of Hawai'i.

I998 Indigenous Knowledge and Empowerment: Rural Development Examined from Within. The Contemporary Pacific I0:289-3I 5.

Gegeo, David Welchman, and Karen Ann Watson-Gegeo

I999 Adult Education, Language Change, and Issues of Identity and Authenticity in Kwara'ae (Solomon Islands). Anthropology and Education Quarterly 30 (I): 22-36.

200 I “How We Know": Kwara'ae Rural Villagers Doing Indigenous Epistemology. The Contemporary Pacific I3:5 5-88.

Goebel, Allison

I998 Process, Perception and Power: Notes from "Participatory" Research in a Zimbabwean Resettlement Area. Development and Change 29 (2): 277-306.

Hanlon, David

I998 Remaking Micronesia: Discourses Over Development in a Pacific Territory, I944-I982. Honolulu: University of Hawai'i Press.

Harding, Sandra

I993 Rethinking Standpoint Epistemology: "What Is Strong Objectivity?” In Feminist Epistemologies, edited by Linda Alcoff and Elizabeth Potter, 49-82. New York: Routledge.

Hirtz, Frank

I998 The Discourse that Silences: Beneficiaries, Ambivalence Towards Redistributive Land Reform in the Philippines. Development and Change 29 (2): $247-276$.

Hobart, Mark, editor

I993 An Anthropological Critique of Development: The Growth of Ignorance. New York: Routledge.

Kabutaulaka, Tarcisius

I999 The Guadalcanal Issue: A Frank Talk. Circulated electronically.

Kabutaulaka, Tarcisius, and others

I999 The Guadalcanal Peace Rehabilitation Project. A draft project proposal of the Canberra Group. Canberra: Australian National University.

Keck, Verena, editor

I998 Common Worlds and Single Lives: Constituting Knowledge in Pacific Societies. New York: Berg. 
Lakoff, George, and Mark Johnson

I999 Philosophy in the Flesh: The Embodied Mind and Its Challenge to Western Thought. New York: Basic Books.

\section{Lal, Brij V}

I988 Power and Prejudice: The Making of the Fiji Crisis. Wellington: New Zealand Institute of International Affairs.

1992 Rhetoric and Reality: The Dilemmas of Contemporary Fijian Politics.

In Culture and Democracy in the South Pacific, edited by Ron Crocombe and others, 97-II6. Suva: Institute of Pacific Studies, University of the South Pacific.

2002 Making History, Becoming History: Reflections on Fijian Coups and Constitutions. The Contemporary Pacific I4:I48-167.

Lal, Brij V, and Hank Nelson

I995 Lives Across the Sea: Colonial Inheritance in the Post-colonial Pacific. Brisbane: Pacific History Association.

Lave, Jean, and Etienne Wenger

I99I Situated Learning: Legitimate Peripheral Participation. London: Cambridge University Press.

Lerner, Daniel

I964 The Passing of Traditional Society: Modernizing the Middle East. New York: The Free Press.

Mamaloni, Solomon, and others

1999 The Guadalcanal Social Tension: Options for Conciliatory and CostEffective Resolution. Solomon Islands Government Opposition White Paper, c. January. Honiara: Solomon Islands Parliament.

Moore, Clyde

I985 Kanaka: A History of Melanesian Mackay. Port Moresby: Institute of Papua New Guinea Studies and University of Papua New Guinea Press.

Nader, Laura, editor

1996 Naked Science: Anthropological Inquiry into Boundaries, Power, and Knowledge. New York: Routledge.

Nyerere, Julius, and others

I990 The Challenge to the South: The Report of the South Commission. Oxford: Oxford University Press.

Pieterse, Jan N

I998 My Paradigm or Yours? Alternative Development, Post-Development, Reflexive Development. Development and Change 29 (2): 343-373.

Pieterse, Jan, and Bhikhu Parekh, editors

1995 The Colonization of Imagination: Culture, Knowledge and Power. London: Zed.

Resnick, Lauren B, John M Levine, and Stephanie D Teasley, editors

I99I Perspectives on Socially Shared Cognition. Washington DC: American Psychological Association. 
Roughan, John J

I986 Village Organization for Development. PhD dissertation, University of Hawai'i.

I99I Solomon Islands Country Paper. Honiara: Solomon Islands College of Higher Education.

I997 Solomon Islands Nongovernment Organizations: Major Environmental Actors. The Contemporary Pacific 9: I 57-I 66.

Scoones, Ian, and John Thompson

I994 Introduction. In Beyond Farmer First: Rural People's Knowledge, Agricultural Research and Extension Practice, edited by Ian Scoones and John Thompson, I-I2. London: Intermediate Technology Publications/IIED.

Singh, Naresh, and Vangile Titi, editors

I995 Empowerment:Towards Sustainable Development. AtlanticHighlands, $\mathrm{NJ}$ : Zed.

Solomon Islands Government

I985 National Development Plan, I985-1989. Honiara: Solomon Islands Government.

I989 Strategies for Provincial Governments Funding System, I989-I993. Honiara: Solomon Islands Government.

I999 Honiara Peace Accord (text). Solomon Star, I4 July, Io-I I.

Solomon Islands Ministry of Finance

I990 Solomon Islands Report of the Census, I986. Honiara: Solomon Islands Government.

Solomon Islands Statistics Office

I992 Solomon Islands Statistical Bulletin (No. I I/92): Education Statistics. Honiara: Solomon Islands Government.

Taylor, David R F, and Fiona Mackenzie, editors

I992 Development from Within: Survival in Rural Africa. London: Routledge.

UNiCEF, United Nations Children's Fund

I993 A Situation Analysis of Women and Children in the Solomon Islands. Honiara: Government of Solomon Islands.

Warren, Michael, Jan Slikkerveer, and David Brokensha, editors

I995 The Cultural Dimension of Development: Indigenous Knowledge Systems. London: Intermediate Technology.

Watson-Gegeo, Karen A, and David Welchman Gegeo

I985 Kwara'ae Mothers and Infants: Changing Family Practices in Health, Work, and Childrearing. In Infant Care and Feeding in the South Pacific, edited by Leslie Marshall, 235-244. New York: Gordon and Breach. 
I990 Shaping the Mind and Straightening Out Conflicts: The Discourse of Kwara'ae Family Counseling. In Disentangling: Conflict Discourse in Pacific Societies, edited by Karen A Watson-Gegeo and Geoffrey M White, I6I-233. Stanford: Stanford University Press.

1992 Schooling, Knowledge, and Power: Social Transformation in the Solomon Islands. Anthropology and Education Quarterly 23 (I): I0-29.

I994 Keeping Culture Out of the Classroom in Rural Solomon Islands Schools: A Critical Analysis. Educational Foundations 8 (2): 27-55.

2002 The Critical Villager: Transforming Language and Education in Solomon Islands. In Language Policies in Education: Critical Issues, edited by James W Tollefson, 309-337. London: Lawrence Erlbaum.

\section{Abstract}

We show in this article how modernization, disguised as "community development," continues to fail rural villages in Solomon Islands despite the supposed movement toward a more people-centered, bottom-up philosophy in development education and practice. We focus on the case study of a Kwara'ae (Malaita island) rural, locally owned and operated project aimed at giving unemployed male youth a stake in the community and preventing their off-island migration. Successful for a decade, the project was destroyed by the intervention of a retired government official who, because of his education, training, and work with outside development agencies, imposed a modernization framework, including centralization of leadership and the valuing of Anglo-European knowledge over indigenous knowledge. While agreeing with the theoretical argument for indigenous knowledge in development, we argue that it is equally important that development be guided by people's indigenous epistemology/ies and indigenous critical praxis for (re)constructing and applying knowledge.

KEYWORDS: rural development, community development, youth, indigenous epistemology, Kwara'ae, Solomon Islands 